\title{
DOCUMENT
}

\section{FOR A COMPROMISED HISTORY OF EDUCATION ${ }^{1}$}

Conference closing $10^{\text {th }}$ Luso-Brazilian Congress on the History of Education

Paths and challenges in the Luso-Brazilian History of Education, Curitiba - 28 august 2014.

\author{
Luís Alberto Marques Alves \\ Porto University, Portugal.
}

\section{$\cos 80$}

\section{The role of the humanities and of History}

n his fascinating work My unwritten books (2008), George Steiner addresses the issue of the Humanities, specifically education reform, secondary and higher education, and we realize that the only way to consistently and effectively defend this cause today is to reach far beyond the repetitive commonplaces, which often lead us to useless feelings of absence that bear no relation to the serious thinking about the fight against ignorance and mediocrity. The Compared Literature lecturer talks about the need to reintroduce stringent criteria that enable the establishment of an order of merit that distinguishes "the authentic excellence of forms of parasitism that today proliferate like mushrooms". For this purpose, it is important to realize that knowledge and understanding must adapt to the requirements of the modern world. Why do we refer to Steiner's concern? Precisely to stress that the Humanities are inseparable from the natural world and the motions of spirit. We are faced with pedagogy of hope focused on the humanistic culture and on the search for the vital balance between the two cultures, to which Charles Snow referred. Etymologically, the word school derives from the Greek scholé, which means the place of idleness, the time needed to develop reflection and the ability to think. And so we find the homo cogens and the homo ludens, capable of discerning the spirit in mathematics, the humour in music, the game in architecture, and the beauty in molecular structures, capable of combining pleasure and demand, as only pleasure can strengthen

\footnotetext{
${ }^{1}$ This paper is financed by National Funds through the Foundation for Science and Technology - FCT, under the project PEst-OE/HIS/UI4059/2014. 
demand, and only demand can make pleasure effective. However, the author of $M y$ unwritten books does not succumb to the temptation of easiness and optimism: "the hope of preserving or revitalizing humanistic literacy in any traditional sense seems to me unrealistic. That literacy, that dominion of the classical, belonged to an elite". The democratisation of schooling and political society runs directly counter to the reasoning of restricted circles based on privilege. So, enhancing the Humanities is a matter of social and cultural survival, since without memory society will commit suicide. George Steiner's main concern has to do with the absence of political courage that is able to fight against and deter the generalized contempt for intellectual life and the distrust in recognising value, "raised by the mass consumption scheme of late capitalism". Intellectual life and the recognition of value suggest that there are certain things that are better than others, and each person's skills and merit should be differentiated. This is where the importance of the Humanities must be valued. Steiner even speaks of the danger of the lack of these things as a "black hole at the heart of the university realm", because they allow us to become entrenched in modern-day problems, responsibility and public action, to have a new understanding of the world and a new awareness of the space we take up in the world.

If you remember, António Nóvoa spoke along this line of reasoning in July 2012, at the opening of the Luso-Brazilian conference in Lisbon, drawing our attention to the role that History can and should have as the strand of the Humanities. He referred to History as a scientific genre - History-Science - or a literary genre - Fiction -, but especially as a History of and in the Present, that refuses the useless knowledge, from the perspective of Jean François Revel, and assumes itself as a strand of knowledge without condition and committed to public action.

Towards the end of my intervention, I will come back to this link between the past and the future, between heritage and the ground that must be treaded, between the foundations of thought and the volatility of decisions lacking scientific support. For the time being, my aim is to work towards the recognition of our historical and educational specificities, and then make some suggestions as to how we can use them and, consequently, our particular way of dealing with them.

\section{The identity and specificity of History}

All of us who work with History, whether in academic, scientific, literary, romanticized terms, in professional terms as agents that share historical knowledge, or even simply out of curiosity for the contextual space - local, national or global - surrounding us, have often questioned ourselves about the meaning of this humanistic knowledge that gives us our identity and links us our past roots. To underpin and justify our perspective, we could base our comments on the words, phrases or ideas of many historians to corroborate the defence of our scientific space. Instead of comfortably relying on that potentially biased attitude, I would prefer to share the justification given by a sociologist in May 2013 at a congress on contemporary history held in Évora, at a round table discussion on History and the Social Sciences, who decided to list the aspects - he called then lessons - that History had provided him throughout his training, and which he could not or has not been able to do without. In a perspective that embodies the intellectual sharing between the various Social Sciences, he said that History should first be regarded as a way of thinking, 
and that facts must be examined as processes thought of over time, hence the sense of process and the scientific uniqueness of work, with time being regarded as specific aspects limited to an unquestionable scientific nature.

For us, however, the lessons he learned from History, which he holds to in his work as a social scientist, alert us to aspects that we often do not remember or have little regard for, but which ultimately justify our attachment to science.

First, he believes that only History can help place the variable of time at the centre of research or of social-scientific questioning. This attitude allows us to grasp the consistency of social structures, understand human societies as a constant development, interweave times that associate diachrony to dysshynchrony, have a different way of looking at time matches, sequence and mismatches that can lead us to parallelisms of events in different spaces, to apparent repetitions of successes, or to the discomfort of feeling that we have not learned from the mistakes of History.

Secondly, he refers to Geertz (2008) and his essays in interpretative anthropology to show that we often simply read over the shoulders of actors, performing a process of social metaconstruction that does not take into account understanding others understandings. Geertz shifts the discussion on the charisma of the purely psychological or sociological field to the field of cultural and, therefore historical phenomena that involve individuals and feed the concepts of their dominance and power. As such, we are led to believe that western policies are permeated with a symbolism that gives it meaning and even defines its nature. In this scientific construction process, the irreplaceable role that History will have to undertake is unquestionable.

Thirdly, and again referring to the sociologist in Évora, he states that the past is among us. There is some evidence behind this statement: on the one hand, the reference to the facts - one-off or repetitive - only makes sense when they are part of the social processes, of the long-term structures; on the other hand, the current relevance of the structure lies in the past it embodies, and this is why it is important to make it the subject of History. By defending the perennial over the occasional by no means pushes the occasional to the background. Rather, it gives it meaning, provided it is part of an explanation that exceeds the shortest period of time to give it more meaning and consistency.

Fourthly, to substantiate the absolute necessity of History in his work, he emphasises that the social and scientific explanation embodies - and takes shape with - the description and narration. To explain is not the opposite of to describe, because the explanation thickens the narration and the description. If we accept that scientific relativity is a way of being in science - social or otherwise -, then we will have to accept that every explanation is accidental and unique. Consequently, all models are experimental in explaining unique processes, and the explanatory framework must coincide with the analytical approach. Therefore, we need not hide from the subjectivity of History, from the various possible interpretations, from the different readings of events, from the need to look for a truth that does not exist in any socials science. This the habit that the subjectivity of History has made us accustomed to: it allows us to take into account what the other says, thinks, defends, justifies ... giving us the maturity to claim an irreplaceable space within the Humanities. 
On a fifth and final note, we find much of what surrounds us and happens today because of History. The sociologist stated that "the prospect based on study and comparison of the cases analysed is better than the mechanicist prediction". The world we live in today likes to generalise. We exist side by side with a journalism that likes to emphasise what brings in audiences. We share airtime listening to commentators that transform everyday episodes into inevitable predictions. Historians are generally called to these stages to confirm the analyses these commentators make, but they are not given time enough to share the explanations that only consistency of time can provide. Again, this is another reason for us to understand well what the singularity of our science has in store for us, in all places or stages we are allowed to use.

Let us now accept the debatable challenge on our usefulness, whether of the Humanities in general or of History in particular, and let us clear arguments to add to the views of the others. What are our arguments?

\section{What is the purpose of History and historians?}

If other social researchers believe that the value of History is irreplaceable, what will the main stakeholders believe in? I would now like to shift from an epistemological perspective, of the nature of knowledge and how to integrate and build it, to a perverse view - especially as to how it is expressed in scientific terms of usefulness, of social and economic meaning - which we are not afraid to face, mainly because it also helps us to sustain our identity.

I would like to begin with a flagship sentence written by Paulo Freire in 1993: "It is in History as possibility that subjectivity takes on the role of a subject, and not just that of an object of the transformation of the world. The future then stops being inexorable and becomes that which it is historically: problematic (p. 69).

Two works recently published in France have marked and systematised many of the random ideas in my mind. First, the work supervised by Christophe Granger - $\grave{A}$ quoi pensent les historiens? Faire de l'histoire au XXle siècle - published in 2013 and, second, a work published in late 2010 , supervised by Emmanuel Laurentin - $A$ quoi sert l'Histoire aujourd'hui?, commemorating the $10^{\text {th }}$ anniversary of a programme entitled La fabrique de I'histoire, with a collection of testimonials from 40 historians in answer to the question in the book's title.

We believe some answers will give greater consistency to our thinking.

Bénédicte Savoy ${ }^{2}$, for example, believes that studying and teaching history - an interdisciplinary and transnational history sensitive to the effects of social and intercultural contributions that establish connections between the fields studied demonstrates humanity, and so we go back to Steiner.

Julien Vincent ${ }^{3}$ prefers to emphasise his role in "clarifying the present", to "building a time and geographical (spatial) framework of reference, in which phenomena gain meaning", yet he draws our attention to the fact that "the issue of the usefulness of history is not an issue of school alone, but also an issue of politics" and, therefore, he alerts us to the "use" made of it; moreover, and in line with other authors - among which I would

\footnotetext{
${ }^{2}$ Professor of Art History at the Institute of Art History and at the Technische Universität of Berlin.

${ }^{3}$ Assistant professor at the University of Besançon, specialises in $19^{\text {th }}$ century History of Great-Britain. Hist. Educ. (Online) Porto Alegre v. 19 n. 45 Jan./apr., 2015 p. $187-206$
} 
highlight the Portuguese historian Borges Coelho and the Italian Enzo Traverso in his masterpiece on Uses of the past - , the need for options when choosing and articulating facts, and when clarifying the lines along which the narrative is built.

Along the same line of reasoning, Sophie Coueré ${ }^{4}$, expert in the history of Russia, of the USSR and of communism, exemplifies with the decree on the Archives signed on 1 June by Lenin, stipulating that the use of documents should be made in the interest of socialist construction. Coueré stresses the critical nature we should assume epistemologically in its construction and reading.

Judith Lyon-Caen ${ }^{5}$ prefers to emphasise the role of history as a tool for elucidating the role that each individual has in its relationship with the other, in a perspective which is not expressed at all as "the curiosity of the antique dealer, but as ethnological", in other words, "the other (either the individual past - the personality - or the collective past) is not the inhabitant of a distant country, but the one who lives in the past". The view held by Boaventura Sousa Santos on the "scientific Guantanamos" helps us skip over the singularities and head straight towards scientific partnership.

Jean-Noël Jeanneney ${ }^{6}$ goes further because he believes that without history "young people will live in a world they don't understand, and citizens will be bombarded with reports/ news /facts about which they can not substantiate any argument (a judgement) in the present". So, without history, clarity will never be the basis for building a truly participated and conscientiously assumed democracy.

Isabelle Heullant-Donat ${ }^{7}$, an expert on the Middle Ages, stresses its subjective nature to highlight the relevance of its epistemological credibility: "historians know that history is neither the science of the past, nor the science of truth: history reconstructs certain facts, beliefs, discourses, but its purpose is to explain and not to justify the changes that have occurred in human societies. History is knowledge that mobilises methods, concepts, and whose contents / object is time". She adds that "history serves mainly to fight against ignorance and to end simplistic judgements about the past". Similarly, Jean-Clement Martin ${ }^{8}$ considers that "history serves to legitimise claims, to ease sufferings, or to mobilize against injustices". On this interpretation, "Une histoire du monde global", a work supervised by Philippe Norel and Laurent Testot published in 2012, or La guerre: des origines à nos jours published in 2014, take us to the plurality of spaces and the permanence of phenomena that only History can withdraw from the apparent novelty, providing us with tragic repetitions achievable by the absence of memory made clear by this scientific knowledge that knows how to deal with time. In this sense, we need to also use it to fight against oblivion.

In order to conceive History in the $21^{\text {st }}$ century, historians need to refine their method, to produce research work taking into account plurality, interdisciplinary skills, team work,

\footnotetext{
${ }^{4}$ Assistant professor at the École Normale Supérieure of Ulm, specialist in the history of representations of Russia and the USSR, and in the history of communism.

${ }^{5}$ Historian, assistant professor at the School of Advanced Studies in Social Sciences - Centre of historical Research -, studies the relationships between literature and society in modern France, $19^{\text {th }}-20^{\text {th }}$ centuries.

${ }_{7}^{6}$ Lecturer of contemporary history at the Institute of Political Studies in Paris.

${ }^{7}$ Lecturer at the University of Reims-Champagne Ardenne.

${ }^{8}$ Professor emeritus of the Panthéon-Sorbonne University, and former director of the Institute for the History of the French Revolution.
} 
narrative imagination, the art of telling - or retelling - stories, integrating new themes genre, trends, the subjects, the marginalised, the minorities. The other work we have mentioned, by Christophe Granger, À quoi pensent les historiens? Faire de l'histoire au XXle siècle, is developed along these lines, showing that the purpose of the various Schools of History is the same: lend credibility to historical knowledge, defending it within the context of an overall education (of young people), allowing the unique skills that only History can develop to help the present be more inclusive, more understanding and less politically manipulated. So, justifying its existence is not just a matter of usefulness, it is a matter of the survival of humanity.

Following the perverse pathway, which we do not claim to avoid and even dare face, let us move forward to another scientific area that places us within the production of knowledge in the field of the Humanities.

\section{What is the purpose of education?}

If we now know why we should not give up on investing in credibility, on generalisation, on fighting for History, we should then find out where Education is as a place for developing science, but also as knowledge vindicated by various social, economic, political, and cultural organisations, to name but the most frequent ones. In a recent interview to a biweekly newspaper in Portugal, António Nóvoa, who is now experiencing a close contact with the Luso-Brazilian environment of education, stated:

The worst news for Portugal would be for people to drop out of school, because one of the values passed down since the April Revolution 40 years ago is the belief in Education. [...] We need to bring education and science into economy and society [...]. Several challenges (lie ahead): [...] we have managed [in Basic education] to create a school for all children and young adults, but we have not yet achieved a school where everyone learns. That is, we have won the battle of attendance, but still need to beat the battle of learning. [...] School makes no sense to many students. [...] We need to have a school focused on learning and we need to strengthen the public space of education. [...] But society also needs to understand that education is not confined to school [...]. It is the metaphor of the educating city. We need more teaching freedom [...] fostering a collaborative and participative education. [...] Portugal must believe in school and scientific culture [...] vital factors of our cultural and political independence. [...] Portugal needs another view on democracy, development and integration in Europe and in the global world, and to unite two key pillars: knowledge and territory, science and society, the universities and the companies. (Nóvoa, 2014, p. 1-4)

Education thus appears within a framework of political importance, choices that governments must make and implement, of a social and economic aspect, as a means of social integration/inclusion, but also of economic productivity, as a social and community challenge, in the perspective of the educating city or society, but also as a space for personal - students - and professional - teachers - achievement. This convergence also coexists with the educational and didactic laboratory that constitutes the school, the classroom, or just the educational environment. 
If we look at the characterisation of History throughout time, we can pinpoint the path that takes us from the Age of Enlightenment to the $21^{\text {st }}$ century challenges - see, in particular, the work coordinated by Roberto Carneiro: 2020: 20 anos para vencer 20 décadas de atraso educativo, and also the excellent book by Justino Magalhães, Da cadeira ao banco: escola e modernização nos séculos XVIII-XX, which lets us situate the roots of this prospective study in history. This journey - past, present, and future - takes us from a school as a place for the elites to the school as a laboratory of innovation, interspersed with discussions on the sense of social reproduction that may have characterized it. In the Portuguese case, the journey begins abroad, with the acceptance of the models that would later be imported and tested in a favourable political context - for e.g., Pina Proença, Ribeiro Sanches or Verney, to name the more representative, are leading names of these new investments. However, innovation also brought with it a new role for the State as a focal point for boosting and controlling the education-related initiatives. From this moment on, the value of Education is regarded as a prerequisite for freedom, citizenship, a more active political involvement, but also for the consumption of cultural products, meaning the press, and later the cinema, opera, music, museums, etc. Those of us in this profession as historians are conscious of this consistency of time, but sometimes doubt whether this process of the school fulfilling its responsibilities, while at the same time those of the families are being emptied, was not based on a self-interested perspective, on an immediate usefulness, to shape the individuals into having a useful behaviour, yet rather retrained to more easily controllable spaces. The massification of education, either by searching for the best methods, either by instituting the contents considered to be the most appropriate, either by finding assessment models characterised by quantity and systematization - first at national level, and later, in the $20^{\text {th }}$ century, at international level -, was clearly heralded by those who defended the importance of school, education, literacy, technical training, the training of agents, the supervision of school books and programmes, the need for inspection, the importance of international benchmarking.

The best evidence of the ubiquity of power within the school and, consequently, within public education upheld ad nauseam in political discourses, is when, using the method of comparison so brilliantly advocated by António Nóvoa in the opening conference of Cihela in Mexico in May 2014, we look at the different political contexts, for e.g., the Portuguese and the Brazilian contexts, and try to find the elements that define and describe their educational policies.

Would the so-called Imperial period between 1822 and 1888 not be similar to our Age of Enlightenment (1750 to 1777) and Liberalism established once and for all in 1834? Do the concerns with primary education - see the General Law of 15 October 1827, for e.g., or the Decree 1331A of 17 February 1852 - not refer to the same type of initiatives that marked our History of Education from Pombal - Charter of 6 November 1772 establishing and formalizing basic education - to the Reform implemented by Rodrigues Sampaio on 2 May 1878? Incidentally, these reforms were not enough to prevent Portugal from having more than $70 \%$ of illiteracy in 1872, at the time of the Republic, as in Brazil, for a population of about 10 million, where only 150000 students were enrolled in primary schools, and the illiteracy rate was of $66,4 \%$. However, during this stage the concerns 
relating to vocational training - technical studies or schools of applies arts -, to teachers' training, normal schools, to private education, colleges or boarding schools, or to higher education - faculties, schools for higher education, academies - were mostly the result of interventions where the political power was called to participate and, obviously to inspect the General Inspectorate of Primary and Secondary Education was established in February 1854 in Brazil and in 1870 in Portugal ${ }^{9}$.

The Republican phase, which started earlier in Brazil (1889) and ended a little later in Portugal - 1929 in Brasil an 1910-1926 in Portugal - is centred on problems other than the ocean distance between the two countries: the creation of an Education-specific ministry in the Brazilian case, interestingly, combining Public Education with the Post and Telegraph -, secularizing school as much as possible, investing in a more diversified higher education (academies, institutes, study centres), introducing reforms to break with the past - 1911, 1918, and 1923 in Portugal, and the reforms introduced by Rivadávia Correa, Carlos Maximiano and João Luiz Alves in Brazil. In both countries, generosity and utopia go hand in hand, tending a little more towards the Republican model in the case of Brazil, with the $2^{\text {nd }}$ Republic between 1930 and 1936, and interrupted by the emergence of Estado Novo [New State] on 28 May 1926 in the Portuguese case. It is also interesting that educational bridges existed in spite of the political differences. The period between the late 1920 s and the early 1930 s is the best time to single out the proximity of ideologies and educational principles in the New Education movement in Portugal and in the Manifesto dos Pioneiros [Manifest of Pioneers] in $1932^{10}$. Among the key ideas exposing the desire for change, we find: "in the hierarchy of national problems, none is more important or more serious than education"; "the new education must be a categorical, intentional and systematic reaction against the old, artificial and verbal education service, set up for an outdated system"; or "if the purpose of education is, above all, to develop the vital ability of the human being to the fullest, then the educational function should be considered as 'one', with various levels intended to serve the different growth phases, which are organic parts of a whole that biologically must be brought to the individual's full training". These sentences from the Manifesto reflect the political and educational environment that reaches far beyond the spaces where these ideas circulate.

The Estados Novos period - in Brazil from 1937 to 1945, and in Portugal from 1926 to 1974 - enables us to find a moment when some of earlier achievements entered hibernation: in the case of Brazil, and in this area, the 1937 Constitution lost educational strength compared to the one of 1934. In the Portuguese case, the break with the Republican past becomes stronger, and courses, programme contents, ideological and

\footnotetext{
9 "As an organised activity, education has always been directly controlled by whoever held the power, or by its representatives. This was also the case in Portugal: while the Church controlled education, it also controlled its schools; as the State claimed a foothold in public education, this function was taken over by its officials. When the Ministry of Public Education was established, the problem was addressed with objectivity, with the target of institutionalizing school inspection as a body with specific functions [decree of 16 August 1870]" (Carneiro, 2003, p. 21).

10 The Manifesto dos Pioneiros da Educação (1932) is the arrival point (1932) of a reflection of Brazilian reformers heralded by Adolphe Ferrière in 1930, namely Fernando Azevedo and the 1928 Reform, or Lourenço Filho, head of Public Education in the state of S. Paulo in the 1920s. The Escola Nova experiments impacted more on the public schools, through public education reforms developed in the education systems of various states in the 1920s, and early 1930s in Rio de Janeiro.
} 
professional supervisory structures were established in line with the Estado Novo model. Interestingly, both countries are concerned about professional and technical matters, for e.g., the reform of technical education in Portugal in 1948, the creation of Senai in 1942. In Portugal, the 1948 technical education reform implied the creation of a preparatory cycle extended to secondary education, the purpose of which was to offer a vocational option at a later stage to ensure a more consistent cultural structure - upholding the idea of the labourer who executes but who also thinks; artistic education ensured more room for creativity, instead of simple repetition; and, in high school, more room for study visits and extracurricular activities.

The next phase, albeit in different political environments - in Brazil, the New Republic period between 1946 and 1963, and Portugal still under the Estado Novo - I would highlight the post- $2^{\text {nd }}$ World War concerns about the high illiteracy rates, which would draw decisions closer between both countries: in Portugal, the Popular Education Plan, the Regional Mediterranean Project (published in 1964) ${ }^{11}$ and Telelearning to allow for the widest possible literacy and schooling among young people and adults. In Brazil, especially during the New Republic period (1946-1963), the establishment of the National Trade Learning Service - Senac - in 1946; the Magna charter of 1946; law n. 4.024 of 20 December 1961 - Guidelines and Base Law on National Education; and the establishment of the national Education Board and State Councils aiming for the proximity with the populations' needs; the establishment of Popular Education Centres, the National Campaign to Eradicate Illiteracy - CNEA - in 1958, and the conferences on adult education or the meetings to discuss literacy and popular culture in 1963. Despite the political divergences, the above are indicative of some similar concerns. Emphasis should be laid on some initiatives led by those who signed the dos Manifesto of Pioneers, for e.g., the Popular Education Centre inaugurated by Anísio Teixeira in Salvador, in the state of Baía.

This phase is a good example of the external, international, and overall influence on the decisions of the different countries. Even if we were to expand the area of analysis, we would find the same concerns because the international organisations (for e.g., the OECD or Unesco) started to influence the domestic political agendas on education and the role of private, public, secular and religious schools. In fact, the Portuguese Estado Novo, through its minister of National Education, Galvão Teles, acknowledges it in the order authorising the publication of the report dated 2 April 1964, thanking the collaboration with the organisation for Economic Cooperation and Development. It states: "I hereby determine that the report be taken into consideration [...] as a preliminary study, being of considerable value, for planning purposes"

During the military rule (1964 to 1985), Brazil was influenced by some of Portugal's examples, especially those related to the aftermath of Humberto Delgado's defeat following the 1958 elections: the arrest or dismissal of teachers, the invasion of universities, the arrest of students, the banning of students' associations, and, in the Portuguese case, the sentence of the military draft to the Colonial War. Interestingly, this is also the time when new universities and faculties were established, earlier in the case of Brazil - the University of Brasília opened in 1961, and later in the Portugal, in the 1970s in

\footnotetext{
${ }^{11}$ Projecto Regional do Mediterrâneo. Evolução da estrutura escolar portuguesa (metrópole. Previsão para 1975. Lisboa: Instituto de Alta Cultura/Centro de Estudos de Estatística Económica, 1964. 
Aveiro and Minho, under the rule of Marcelo Caetano. Economic growth also required a greater investment in literacy, yet the regimes were not always willing to accept the civic consequences of a widespread education. The extinction of the Mobral Movement Brazilian Literacy Movement - or the contents of the 1971 Law on the Guidelines of National Education show the politicization of education. The hidden legacies of great educators, such as António Sérgio, Jaime Cortesão, and Rui Grácio, or in the Brazilian case Anísio Teixeira, Fernando Azevedo, and Paulo Freire, to same but a few, had to wait in the hope of better days or opportunities ahead.

After 1974 in Portugal, and 1986 in Brazil, the political opening brought about a new education programme, which was then discussed openly and democratically, bringing together pedagogues, teachers, parliamentarians and politicians in a framework of renewal that has lasted until today. The initiatives appeared in new areas - LBSE [Basic Law on Education] of 1986 in Portugal, for e.g., - new national curricula (Brazil), literacy programmes or campaigns - for e.g., the National Literacy and Citizenship programme established in 1990 in Brazil aimed to reduce the number of illiterate people by $70 \%$ by 1995 -, and a greater internal control - the reintroduction of exams - and external control, through the participation in international programmes, for e.g., Pisa.

Following these considerations, let us return to the interview with António Nóvoa, and also to the perception, which is what matters most to us, that education, whatever its future challenges, with a foothold in History, allows us to examine the continuities, proximities, repetitions concealed behind seemingly innovative messages. Moreover, and this comparison has helped us illustrate the point, that regardless of the space, which we could now even extend to Europe or Latin America, we will need to know how to use this past studied along a diachronic and synchronic dimension. This means that when we speak of a fact that is much more than an episode, we historians of education need to find ways of getting the message across over time and over the three-dimensional space. The most significant is that we can show that the concern in dominating the school has enabled the results of schooling to be vexatious, vindictive and unsubdued.

Treading the path of informed impudence again leads us towards the school, but the education we aim does not tolerate nor submit to political control, because the more appropriate training of agents and the knowledge bases of their contexts oblige us to consider new directions and new challenges for the school. Politically speaking, the EU logic today can be better explained compared to the state's logic; the excessive dependence on central powers ought to be replaced by an increasing autonomy of peripheries over the centre; the school as a technical object and a victim of the strangleholding bureaucracy ought to be replaced by a civic-political space in the most classic sense. In terms of culture, the history of education has shown that the culture of subordination has not guaranteed integration, that homogeneity has subverted diversity, and that isolation has made national and international partnerships more difficult. The History of Pedagogy has shown that the processes of massification, standardized and with limited room for manoeuvre by the agents operating on the ground, have not valued differences, that programmes monitored through control and quantification mechanisms even entitled to rankings - ought to be replaced with flexible curricula, so that the school of 
teaching gives way to the school of learning. As Nóvoa stated, we have already "won the battle of school attendance, but we must still win the battle of learning".

If this is the way, then education will still have much to give to countries willing to reinvent themselves at any given time, and in particular at times when the need for collective involvement is at its highest.

Let us therefore associate the two scientific fields that we have briefly described History and Education.

\title{
The heritage of accomplishments and future challenges
}

What is the purpose of the History of Education? Let me begin this part of my paper with an extract from a novel by Saramago:

\begin{abstract}
Although as a student he did not attend such a school, with all this ceremonial and size, he knew that every school has a director, that every director has an office, that every office has a sofa, [precisely what he needed]. He continued to open and close doors, he looked inside the classrooms where the dim outside lights casted a phantasmagorical shadow, where the students' desks seemed like lined up tombs, where the teacher's desk resembled a shady sacrificial place, and the blackboard resembled the place where everyone's accounts were dealt with. Suspended on the walls, he saw the confused stains left behind over time on the skin of beings and things, the maps of the sky, of the world and of the countries, the river and mountain maps of human beings, the blood channels, the digestive tract, the order of muscles, the communication of nerves, the frame of bones, the bellows of lungs, the labyrinth of the brain, the cross section of the eye, the mesh formed by the sexual organs. Classrooms followed one another along the corridors all around the school, one could smell the chalk everywhere, nearly as stale as the smell of bodies, some people even say that before mixing the clay to form man and woman, God used chalk to draw them on the first night, and this is the only certainty we can hang on to, that we were made from dust, we are dust, and we will return to dust. (Saramago, 1997, p. 96-97)
\end{abstract}

How many of us have observed or studied scenarios, resources, narratives that remind us of this literary description? How many writers have used the school space to situate their characters, have referred to it with the intention of identifying the marks that it has left behind in the leading actors of their stories! This literary usefulness resulting from being aware of its significance in the creation of their characters, but also from the ability to study/read our analyses as historians of education brings us to three final issues I would like to share with you: the History of Education today is called to perform a role that is not appropriate to its social and scientific space; our epistemological work has gained consistency allowing it to increase, today and without any problems, the number of comparative the frameworks and group works in different areas; those who develop scenarios for education in the future can not design or develop those new buildings without paying more attention to the educational legacies that only the History of Education can provide.

Subject, power and disputes over education. This was the theme of the 11 th IberoAmerican Congress on the History of Latin-American Education; Education, War and 
Peace was the theme of the Ische held in July 2014 in London; the Ecer conference European Conference on Educational Research - Porto 2014, to be held from 1 to 5 September Porto chose as its central theme The past, the present, and the future of educational research in Europe"; the $1^{\text {st }}$ Forum on Africa - Education and Development, will be held in Salamanca on 28 and 29 November 2014; The Spanish Society for the study of historical-Educational Heritage will hold the $6^{\text {th }}$ Scientific Conferences entitled Museum Pedagogy: Practices, didactic uses, and research on the educational heritage from 22 to 24 October 2014; in November 2014, we have the International Conference on Education and Social Sciences in Milan; then, in January 2015, in Barcelona, a Conference on Education and the Humanities, covering Multidisciplinarity in Education and in the Humanities; the conference in Seville, between 22 and 23 September 2015, will be entitled School memory - new trends in historical-educational research at international level: heuristic prospects and methodological issues. We could go on, but we all receive every week in our e-mails events to attend, or at least to be aware of, and many calls requesting our presence as historians of education. More than confirm this, I would however like to reflect on what makes us so much in demand and, considering the various themes under discussion, what they need from our scientific production.

First, one of the most obvious characteristics in recent times is the reference to research trends, to heuristic perspectives, to renewed concepts, to the densification of the epistemological framework with which we work, to the expansion of our space of reflection - the term internationalisation/globalization comes up frequently - or to the enrichment of the hermeneutics of sources, more or less often used. There are clear methodological concerns putting us in a comfortable scientific space, with a specific identity, with apparently unquestionable knowledge credibility. In fact, I believe that is why the historians of education are legitimised and their presence is requested for opening conferences, for promoting debates, and for round table discussions involving sociologists, politicians, journalists or historians specializing in other areas. Sometimes it appears that we are called to legitimise options that need a halo of credibility.

Moreover, we also find historians for whom education is their profession, in which they talk about development, about the continuity of peace, how to deal with times of war in educational contents, share teaching experiences between countries, or rank them in terms of (under)development, offering information about what the history of other places and other periods of time tempos can offer us so we avoid building schools, models, or systems that have already been tested and proven, enabling us to apply them but with a different sense of criticism, or even avoid them.

These international places of reflection, however, which we attend whenever we can, also bring out some situations we have to applaud and refer, although we do not need to single them out. First of all, the frequency of the meetings that this scientific community to which we belong organises and shares doubts, methods, results, and concerns. Secondly, the gradual integration of new objects of study - the history of mentalities, everyday life, micro-history, the history of women, education heritage, etc., in the new trends of contemporary historiography contemporânea, and also the interdisciplinarity illustrated in our research, ranging from oral history to sociology, from anthropology to heritage and museology, from economy to pedagogy, from literature to philosophy. 
This is the framework in which we can forecast the terms of reference that enhances identity and avoids constraints. Allow me to introduce, at this stage, a sentence by Bernardete Gatti which seems to be appropriate in this context: "Historically, to be considered relevant and be locally, regionally or more widely embedded in society, studies need to be somewhat overarching, relate to real situations, unequivocally, unambiguously, vaguely or arbitrarily picking up on critical educational issues" (Gatti, 2003, p. 5). Along the same line of reasoning, Christian Grataloup, in a brief essay entitled L'École en manque d'Histoire du monde refers that "the world (global) horizon produces a school requirements that forces the players involved in the educational systems, especially the Western systems, to realize that they are unable to have the same prospects as they have so far" (p. 347). Teachers must assume the plurality - of times and spaces -, the integration of legacies, and the notion that the relationship between memory and history is indispensible in the historical perspective they are conveying to their students. He believes that "global history is a civic necessity, an obligation of the world's citizens" (p. 349), in particular of teachers who are educating future generations.

Thinking along the same lines as Hobsbawn, who, looking at the situation of the $21^{\text {st }}$ century, refers to five major changes that directly or indirectly involve education: the widespread access to education is today presented as an indicator of well-being; advancements made in education have materialised into the majority of the population being literate, making people more free, able to choose and potentially happier; increasing the emancipation and involvement of women in the education of nations and societies; although in some areas access to education still needs to be democratised, the education market is booming and students tend to study longer; the drop in fertility rates is also the result of very high education levels, especially among women, young people tend to stay longer in school and delay their entry into the labour market, and obtain income allowing them to support a family (Hobsbawm, 2000). What kind of scientific commitment do we have to offer to help give more consistency to the needed changes and to the inevitable political decisions?

A reference scenario: in our libraries, in our research groups, in our projects, and in our publications we have evidence that enables us to describe the educational paradigms, which, despite some nuances, have prevailed for more than two centuries. It can be shown that these historical choices were determined by the industrial economy model and by the powerful presence of national education systems controlled by the State, which today demand a new framework where the importance of knowledge is crucial for the options in terms of societies, and economies and cultures we desire in the early $21^{\text {st }}$ century. This is the framework in which the new paradigm of the learning society arises, marginalising the "yoke of techno-bureaucratisation and the liberation from an economic dominance relentlessly exercised in education in recent decades" (Hobsbawm, 2000, p. 47).

A historical perspective linking the past with utopia. If the past takes us to the industrial model, and the present time demand globalisation, what should our contribution be to building a true learning society, reviving the concepts of educating, school, teacher, student, programme, pedagogy, textbook? If in the past we have already identified and described the standardised and routine systems, and in the present we are faced with a more segmented school - sometimes more market-driven or on the basis of arguable 
national or international political choices rather than on the recipients -, how can we help to achieve growing levels of personalization until we achieve a model of a school - as a place for sharing knowledge, but also of learning - on the basis of each individual - utopia? If in the past the objectives of schools were led by techno-bureaucratic - corporate powers, and if today we are seeing various configurations determined by the market, what can we do to bring out the empowered communities, capable of acting, where clarifications go hand in hand with civic engagement and participation ${ }^{12}$ ? I believe we all have some answers, or at least some contributions, to these questions relating to a historically long period of time.

A scientific attitude that renders the episodic ridiculous, the novelty less evident, the national and international rankings inadequate, centrality obsolete, immediate utilitarianism into a way of colonizing education. To fight against these stigmas and these marks that today underestimate the mission of educare, we can show that the alternatives involve placing the school at the centre of the purpose of education, i.e., to give priority to developing the whole person, the person with autonomy and dignity, bearer of a unique and unrepeatable life project, responsible and participating member in its communities of belonging ${ }^{13}$. This is why today we have the involvement of historians of education linked to the definition of themes regarded as fundamental in the perspective of Hobsbawn's guidelines. Themes such as education and territory - learning society, learning cities, school urbanism -, education in citizenship, education for the construction of identities and personal projects, education in the face of the challenge of social diversity and differentiation, the contribution of education to social cohesion, among many others, are, as we have seen, central strands of international meetings where our presence is required, and for which we have to be prepared, both in terms of national - but preferably international - individual projects and especially group projects. In this regard, our experience so far in the ten congresses where we have discussed joint projects and reciprocal knowledge, aligning epistemology, concepts, heuristics, hermeneutics, and themes, now allow us to work along a prospective basis, where our involvement will be the result of the reliable course / pathway we have treaded so far.

\section{Conclusions/suggestions}

The history in crumbs into which much of the history of education has transformed, directly linked to a historiographic conception that has renounced to the concern over the movements explaining society and restrained to unique, singular properties inherent in each educational phenomenon studied [...]. How many times have we seen citations of Saviani, Freire, Libâneo, Bourdieu, Marx, Piaget, Schon, Zeichner, Perrenoud, Nóvoa, Enguita, [...] repeated over and over again because a literature review is not done as an active 'reconstruction', according to a personal interpretative-critical perspective on the theme. (Bittar and Ferreira Jr., 2009, p. 489)

The critical tone of this statement finds echo in the more than a thousand papers presented in the various editions of Luso-Brazilian congresses. In fact, one of the greatest

\footnotetext{
${ }_{12}^{12}$ We follow closely some of the conclusions of the study by Hobsbawm, 2000, in particular pages 46 to 77.

13 Idem, p. 50. 
difficulties experienced by the organizers is that they not only have to find themes that are sufficiently comprehensive so as not to leave anyone out, but they also have to distribute the propositions to the members of the scientific committees that really relate to the themes, sources, methodologies and preliminary results presented. This fragmentation trend, along with an increasing need to find common working fronts to respond to social or financial demands, or to simply prepare some thematic syntheses, forces us to reconsider the course of our scientific area. In this sense, and to maximise the huge legacy left by our research, where should we turn to in order to achieve greater social, individual, national or international commitment?

The path of individual or group works, of synthesis, of the national or compared History of Education type, aiming to systematise the major contribution of the hundreds of works already conducted, enabling us to realize what has already been achieved, but also to identify and diagnose areas of new research. In this regard, the centenary celebrations we often commemorate, and some examples already tested - see, for e.g., Une histoire de l'Éducation et de la formation coordinated by Vincent Troger (2006), or Lecciones de Historia de la Educación coordinated by María Nieves Gómez Garcia (2005), or Historia da educación e da cultura en Galicia by Antón Costa Rico (2004) - can provide references as to what we can and want to achieve. At one time, they used to be very useful for our work or for some university subjects, as simple guides of certain times that served nothing other than guide us across unknown times/themes. We all know how useful these guidelines were for the study of ancient, medieval, modern or contemporary times, or even to learn about the first Portuguese republic, for research work on unknown or less well known topics ${ }^{14}$. I believe that these examples of our joint work need to be developed further: by way of example, let me refer to three books that have stemmed from the projects carried out - Marta Maria Chagas de Carvalho and Joaquim Pintassilgo have edited Modelos culturais, saberes pedagógicos, instituições educacionais. Portugal e

\footnotetext{
${ }^{14}$ Some of the works published disclosing the scientific work of the members of the Portuguese community were collected and summarized by the coordinator of the Department of History of Education Maria João Mogarro. Reference is made to: "in 2010, Joaquim Pintassilgo, Maria João Mogarro and Raquel Pereira Henriques published $A$ formação de professores em Portugal (edição da Colibri), a manual on the theme, summarising the history of primary and secondary teachers' training to the present day. In this same year, António Candeias published his last book Educação, estado e mercado no século XX - Apontamentos sobre o caso português numa perspectiva comparada (Edições Colibri / FCSH of Nova University of Lisbon). Justino Magalhães also published two books: Da Cadeira ao Banco: Escola e Modernização (sécs. XVIII-XX), (Educa, UI\&DCE, 2010), the main purpose of which is to focus on the formation of the Portuguese school system, inspired by an integrative approach to its different situations: statelisation, statisation?, nationalisation, governmentalisation, regimentalisation. All these situations correspond to complex historical times, cross-sectional to the Western world, in which, albeit in a singular way, Portugal took part; and, in 2011, O mural do tempo: manuais escolares em Portugal (Lisboa, Colibri). In 2010, Carlos Manique da Silva published the E-book entitled Publicações periódicas do Ministério da Educação: repertório analítico (1861-2009), kept at the University of Porto. In terms of the press, the E-book $A$ educação nos artigos de jornal durante o Estado Novo (1945-1969). Um repertório cronológico, temático e onomástico, was published by Áurea Adão (Lisboa, IEUL, 2012). In the same collection of E-books, Teresa Fonseca Rosa published in 2013 História da Universidade Teológica de Évora (séculos XVI a $X V I I I)$. In that same year, another important book is published on the Universidade de Lisboa, split into $A$ universidade medieval em Lisboa: séculos XIII-XVI, coordinated by Hermenegildo Fernandes, and séculos $X I X$ e XX, coordinated by Sérgio Campos Matos and Jorge Ramos do Ó (Lisboa, Tinta da China, 2013), prefaced by António Sampaio da Nóvoa when he was the rector of the University of Lisbon. This summary follows another article published in Cadernos de História da Educação, v. 10, n. 2, 2011, p. 89-111, entitled A historiografia portuguesa da educação: balanço da produção recente (2008-2010).
} 
Brasil, histórias conectadas (São Paulo, Edusp, 2011); Edições Colibri have published the final monographs of the projects with the same titles - Escolas de formação de professores em Portugal, coordinated by Joaquim Pintassilgo (2012) and Educação e património cultural: escolas, objectos e práticas, coordinated by Maria João Mogarro (2013).

Dictionaries, whether specifically on educators/pedagogues, or on concepts and epistemology relating to our study area. Again, there is no lack of references, especially to those that have associated the constructive dimension of knowledge with a summary of terms, concepts or actors, that include bibliography of reference. For me, Le dictionnaire des sciences humaines organised by Jen-François Dortier and published in 2004 is a good topic of discussion on what we desire or wish to do. Let me also mention the large directories, especially the printed ones, that have received many contributions and suggested lines of research beyond the strictly educational press, and which take us to a more general press with equally relevant news about education ${ }^{15}$.

Databases, for e.g., of academic work or journals, freely accessed, but which can also be paid to ensure their support, maintenance and constant updating. Moreover, the policy on e-books or on books registered in digital libraries with ISSN references, for e.g., in the Instituto de Educação-Lisboa, in Flup, and also in Brazil, offering dozens of works/articles/journals in accessible format to researchers. However, sometimes we need updated roadmaps or, for e.g., periodical newsletters to be developed by our societies and widely disseminated among us.

In terms of methods, we need to insist on comparative charts, whether because of the research proximity - Portugal, Brazil, Spain, Latin America, ... - or because research centres-groups already exist that can now be developed

In terms of academic work, in particular Ph.D. works ${ }^{16}$, conclusions and theory and practical contributions need to be integrated, addressing other subsequent research work and also their social political, economic, cultural or educational usefulness today.

In terms of themes, we need to embrace the challenges set by Grosvenor, for e.g., but also by other researchers who normally submit different views in our meetings, and

${ }^{15}$ NÒVOA, António (dir.). A imprensa de educação e ensino: repertório analítico (séculos XIX-XX). Lisboa: Instituto de Inovação Educacional, 1993; ADÃO, Áurea (dir.). A educação nos artigos de jornal durante o Estado Novo (1945-1969). Um repertório cronológico, temático e onomástico. Lisboa: Instituto de Educação da U. L. (e-book), 2012; SILVA, Carlos Manique. Publicações periódicas do Ministério da Educação: repertório analítico (1861-2009). Porto: FLUP, 2010. Available at <http://ler.letras.up.pt/ uploads/ficheiros/8036.pdf>.

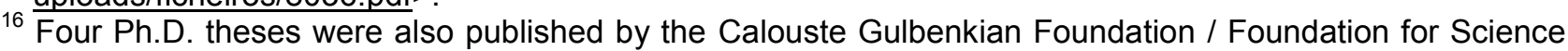
and Technology: in 2010, Discursos legais e práticas educativas: ser professor e ensinar História (19471974), by Raquel Pereira Henriques; in the following year, Lígia Penim wrote $A$ alma e o engenho do currículo: história das disciplinas de Português e de Desenho no ensino secundário do último quartel do século XIX a meados do século XX (2011); Ana Isabel Madeira produced Construção do saber comparado em educação: uma análise sócio-histórica (2012); and Ana Lúcia Cunha Fernandes also published in 2012 A construção do conhecimento pedagógico: análise comparada de revistas de educação e ensino, Brasil - Portugal (1800-1930). Helena Palma has authored the Master's dissertation entitled $A$ matemática na escola primária: um olhar sobre o ensino da matemática nas escolas portuguesas desde o final do séc. XIX até à década de 70 do séc. XX, edited by the Portuguese Association of Mathematics Teachers (Colecção Teses), which constitutes a study on a theme that has so far been ignored in the history of education, in Portugal, in elementary education. More recently (July 2014), Carlos Beato and Joaquim Pintassilgo presented, at Ische, an updated study on the most recent theses defended in Portugal. 
whose experience has pushed us into these new courses. Grovesnor, if you recall, mentioned the need to give space to the history of emotions of students, teachers, staff, inspectors, to understand the meaning of school; the need to embody oral history and autobiographies to understand school culture; the need to rebuild the classrooms and circulation flows.

In terms of research, there have been many individual propositions that we now need to group together, to disseminate and systematise what has already been done in order to move along routes that have already been tapped: for example, the integration of literature as a source of the history of education; the use of gender studies; the articulation with and confrontation between political and ideological views, and the development of educational systems; the analysis of the role of travels, grants, exiles, emigrations/immigration, congresses, (inter)national journals in the consolidation of an educational, pedagogical, institutional thought, in which production often fails to take into consideration the specificities. There have also been works that depart from simple diachronic studies and move towards topics that cut across time, confronting the past with the future. The first result of such an interdisciplinary, group work, which articulates research work by different authors - such as Áurea Adão and Justino Magalhães (2013) - shows also another type of potential work that serves as reference - methodological, conceptual, and epistemological - build interdisciplinary knowledge in terms of human and social sciences - and drives us to other research fronts.

The educational and museological heritage, that has already achieved much but still lacks the standardisation of categories, the proximity of conceptual and analytical languages, dissemination/virtualisation investments, the preparation of thematic workshops, educational services closer to the various audiences, digital/virtual catalogues, documentaries based on reconstructed scenarios, etc., that also serve to enable the individual to share this heritage with credible social and scientific spaces.

The various education degrees/systems can also enhance synthesis studies that highlight the tremendous work already done in the public and private systems, concerning corrective, educating work for elites, religious and secular entities, unions, labourers. In this regard, the recent History of the University of Lisbon and the work entitled Liceus de Portugal are examples of some of the potential of this effort. The interruption of the collection $O$ estado e a educação: séculos XVIII a XX, directed by Jorge Ramos do Ó, was a setback as only the first two volumes were published, on High School Education and Technical Education, even though its aim was to provide reference material for pursuing work in a wide range of fields ${ }^{17}$.

We should also be very careful not to overlook the need to integrate training, in addition to education, with a view to increasing and making our scientific area reliable, to

\footnotetext{
${ }^{17}$ Information given at the presentation of the collection: "The purpose of this collection is to identify and examine the public policies on education, from the establishment of the General Directorate of Studies in 1759 to the current democratic rule [the collection started in 2009]. Its titles could refer to the different education system levels, or address more specific fields no state intervention. The collection constitutes an introductory guide to university students, in particular post-graduate students, and to be a summary for the general public. Each study has been prepared by one or several experts in the history of education, is supported by documentary sources (either in the form of an anthology of excerpts or in full on a CD), and mentions the scientific work produced in the meantime."
} 
avoid being taken over by other scientific areas, for e.g., economy, which can remove its complementary, which is sometimes irreplaceable especially when aspects of education are updated, which sometimes the school has not been able to provide in due time.

It is not my intention to list all the acceptable possibilities. The example given serve to force us into thinking about whether this is the path we wish to tread. I personally believe that to consolidate our scientific area we need to better articulate internally and to have better external visibility. I also believe that the greater our scientific strength, the more respect we will be able to enforce in History, in Social Sciences, and also in defining educational policies. If the planners, the decision makers have already engaged us to afford more consistency to their choices, our scientific area will be stronger if we do not overlook this new social and political usefulness role. During the opening of the $21^{\text {st }}$ Century Dialogues in September 1998, organised by Unesco, F. Mayor told us that "the future is our only heritage that is still intact". To influence the course of the future, we must not give up on thinking about it, but I believe that it will be better if the consistency of our studies provide a contribution that I regard / believe is irreplaceable.

To finish, I will leave you with an image and message by Robert Frost which, in opinion, challenges and urges us to think about the possibility of being different ... and of making a difference!

\author{
I shall be telling this with a sigh \\ Somewhere ages and ages hence: \\ Two roads diverged in a wood, and I, \\ I took the one less travelled by, \\ And that has made all the difference. (Robert Frost - 1874-1963)
}

\title{
Bibliography
}

ADÃo, Áurea (dir.). A educação nos artigos de jornal durante o estado Novo (1945-1969): um reportório cronológico, temático e onomástico. Lisboa: Instituto de Educação, 2012.

ADÃO, Áurea; MAGALHÃES, Justino (org.). História dos municípios na educação e na cultura: incertezas de ontem, desafios de hoje. Lisboa: Instituto de Educação da UL, 2013.

AMBRÓSIO, Teresa; TERRĖN, Eduardo; HAMELINE, Daniel; BARROSO, João. O século da escola: entre a utopia e a burocracia. Porto: ASA, 2001.

BITTAR, Marisa; FERREIRA JR., Amarilio. História, epistemologia marxista e pesquisa educacional brasileira. Educ. Soc., Campinas, v. 30, n. 107, 2009, p. 489-511.

CARNEIRO, A. Henriques. A inspecção do ensino em Portugal: nos finais do século XIX e alvores do século XX. Lisboa: Fundação Calouste Gulbenkian, 2003.

CARNEIRO, Roberto. 2020: 20 anos para vencer 20 décadas de atraso educativo síntese do estudo. In: O futuro da educação em Portugal: tendências e oportunidades. Um estudo de reflexão prospectiva. Lisboa: DAPP do Ministério da Educação, 2000.

CARVALHO, Marta Maria Chagas de; PINTASSILGO, Joaquim. Modelos culturais, saberes pedagógicos, instituições educacionais: Portugal e Brasil, histórias conectadas. São Paulo: Edusp, 2011. 
COSTA RICO, Antón. Historia da educación e da cultura en Galicia (séculos IV-XX): permanencias e cambios no contexto cultural e educativo europeo. Vigo: Edicións Xerais de Galicia, 2004.

DORTIER, Jean-François (dir.). Le dictionnaire des sciences humaines. Auxerre: Sciences Humaines, 2004.

FREIRE, Paulo. Pedagogia dos sonhos possíveis. São Paulo: Paz \& Terra, 2014.

GATTI, Bernardete. Formação continuada de professores: a questão psicossocial. Cadernos de Pesquisa, n. 119, 2003, p. 191-204.

GEERTZ, Clifford. A interpretação das culturas. Rio de Janeiro: LTC, 2008.

GÓMEZ GARCIA, María Nieves (ed.). Lecciones de historia de la educación. Sevilla: Alfar, 2005.

GRATALOUP, Christian. L'École en manque d' Histoire du monde In : NOREL, Philippe; TESTOT, Laurent (dir.). Une histoire du monde global. Auxerre: Sciences Humaines, 2012, p. 347-349.

HOBSBAWM, Eric; POLITO, Antonio. On the edge of new century. New York: The New Press, 2000.

HOLEINDRE, Jean-Vincent; TESTOT, Laurent (dir.). La guerre des origines à nos jours. Auxerre: Sciences Humaines Éditons, 2014.

JUSTINO, David. Difícil é educá-los. Lisboa: Fundação Francisco Manuel dos Santos, 2010.

MAGALHÃES, Justino. Da cadeira ao banco: escola e modernização (sécs. XVIII-XX). Lisboa: Educa/ UI\&DCE, 2010.

NOREL, Philippe ; TESTOT, Laurent (dir.). Une histoire du monde global. Auxerre: Sciences Humaines Éditons, 2012.

NÓVOA, António. Apostar na educação para reinventar Portugal. Jornal de Letras/Educação, n. 1137, ano XXXIV, 2014, p. 1-4.

PROJECTO REGIONAL DO MEDITERRÂNEO. Evolução da estrutura escolar portuguesa (metrópole). Previsão para 1975. Lisboa: Instituto de Alta Cultura/Centro de Estudos de Estatística Económica, 1964.

SARAMAGO, José. Todos os nomes. Lisboa: Caminho, 1997.

SNOW, Charles P. As duas culturas. Lisboa: Presença, 1996.

STEINER, George. Os livros que não escrevi. Lisboa: Gradiva, 2008.

TROGER, Vincent (coord.). Une histoire de l'éducationet de la formation. Auxerre: Sciences Humaines, 2006. 
LUÍS ALBERTO MARQUES ALVES associated professor in Faculty of Arts - Porto University.

Adress: Via Panorâmica, s/n. 4150-564 - Porto - Portugal.

E-mail: laalves@letras.up.pt.

Received on October 3, 2014.

Accepted on November 7, 2014. 